J. Clin. Chem. Clin. Biochem.

Vol. 25, 1987, pp. $15-18$

(C) 1987 Walter de Gruyter \& Co. Berlin - New York

\title{
Clinical Significance and Source of Raised Catalytic Activities of Phosphohexose Isomerase in the CSF in Meningitis
}

\author{
By D. Mathias and G. Schäffer \\ Department of Pediatrics, University of Heidelberg, Heidelberg, Federal Republic of Germany
}

(Received April 1/September 3, 1986)

\begin{abstract}
Summary: The value of phosphohexose isomerase (EC 5.3.1.9) determination in the CSF in the diagnosis of meningitis was tested under routine conditions. In 48 patients with untreated bacterial meningitis, enzyme activity concentrations between 40 and $2335 \mathrm{U} / \mathrm{l}$ were measured, whereas the highest phosphohexose isomerase activity concentration in 92 patients with viral meningitis was $34 \mathrm{U} / \mathrm{l}$.

Lysis of the CSF leukocytes with Triton X-100 resulted in a substantial increase of phosphohexose isomerase activity. In bacterial meningitis these values increased to 200 to $7000 \mathrm{U} / 1$, but remained under $150 \mathrm{U} / 1 \mathrm{in}$ viral meningitis.
\end{abstract}

The raised enzyme activities are derived from the leukocytes and appear to reflect their functional and metabolic state. The information provided by the leukocyte morphology can thus be appreciably extended by phosphohexose isomerase determination.

\section{Introduction}

Rapid delimitation of bacterial from viral meningitis is important in view of the necessity for early treatment (1). In a previous communication, it was shown, on the basis of 29 untreated bacterial and 61 viral meningitis cases, that this delimitation can be achieved simply and rapidly by determination of phosphohexose isomerase in the CSF (2). This determination has been carried out routinely for about three years in our hospital in suspected cases of meningitis.

The following paper reports our experience with this simple determination under routine conditions. A further 48 acute and still untreated bacterial and 92 viral meningitis patients were investigated. The results confirm the usefulness of phosphohexose isomerase assay in the diagnosis of meningitis.

The cause of the increase in activity of this enzyme is to be found in the leukocytes. If CSF samples containing cells are not frozen after lumbar puncture, but stored in the refrigerator or at room temperature, a considerable increase of phosphohexose isomerase activity is observed as a manifestation of progressive lysis of the leukocytes. This effect can be accelerated by treatment of the CSF with Triton X-100. Investigations on isolated cell populations show that granulocytes release very much higher phosphohexose isomerase activities than lymphocytes.

\section{Patients and Methods}

CSF samples were investigated from a total of 146 children with meningitis aged one day to 16 years.

Forty eight patients had an acute untreated bacterial meningitis. The causative organisms were Haemophilus influenzae (19), Neisseria meningitidis (16), Streptococcus pneumoniae (8), Streptococcus group B (4) and Pseudomonas aeruginosa (1). The causes of acute viral meningitis in 92 patients were mumps (15), enterovirus (9), adenovirus (4), herpesvirus (1) or unknown viruses (63). A further six patients with a purulent meningitis had been given initial antibiotic treatment at the time of the first lumbar puncture.

The freshly sampled lumbar CSF was analysed within 30 minutes in each case. The leukocyte count, the differential cell count, the glucose content and total protein content were determined by the usual standard methods. The bacteria were identi- 
fied by means of Gram staining and appropriate culture techniques (3). A viral genesis of the meningitis was concluded from the negative result of the bacterial culture without previous antibiotic therapy, the raised leukocyte count in the CSF and the clinical picture. In addition, a fourfold or higher rise in antibodies in paired sera at the beginning and at a later time in the disease was evaluated as an indication of an acute viral infection. Some pathogens were detected by assay of virusspecific IgM and IgA antibodies.

The phospohexose isomerase activities are measured manually on an Eppendorf photometer with the reagent Testomar ${ }^{\circledR}$ PHI (Behringwerke, Marburg) (4). These measurements require about five minutes. The results obtained in this way are around $16 \%$ lower than those obtained with the Gemsaec Fast Analyzer and the values communicated previously (2). The day-today precision was $5.2 \%(\overline{\mathrm{x}}=\mathrm{U} / \mathrm{l})$ and the deviation from the reference value $5.7 \%$. Admixtures of erythrocytes in the CSF bring about only a minimal increase of the phosphohexose isomerase activity. Nevertheless, the occasional bloody CSF samples obtained by puncture were not included in the study. For lysis of the leukocytes, well-mixed CSF is added to $0.2 \%$ Triton $X-100$ in the ratio $1+1$ and allowed to stand at room temperature for 15 minutes before measurement.

Lymphocytes and granulocytes were isolated by gradient centrifugation with Lymphoprep ${ }^{\circledR}$ as the separation medium (5). Blood from healthy donors diluted in the ratio 1:2 with Hank's solution served as starting material. Lymphocytes were stimulated with phytohaemagglutinin, concanavalin $\mathrm{A}$ or with pokeweed mitogen (Difco, Hamburg) over three days at $37^{\circ} \mathrm{C}$.

\section{Results}

Figure 1 shows the result of these investigations. The phosphohexose isomerase catalytic activity concentrations measured directly in the CSF ( $=\mathrm{PHI}_{\mathrm{dir}}$ ) were between 40 and $2335 \mathrm{U} / \mathrm{l}$. In 12 of these 48 untreated bacterial meningitis cases, the activities were between 50 and $100 \mathrm{U} / \mathrm{l}$, in 23 cases between 100 and $500 \mathrm{U} / 1$ and in 10 cases more than $500 \mathrm{U} / \mathrm{l}$. On the other hand, the highest enzyme activity in viral meningitis was only $34 \mathrm{U} / \mathrm{l}$.

CSF samples were treated with Triton X-100 in order to verify that the phosphohexose isomerase is derived from the leukocytes. However, it was shown that the phosphohexose isomerase activity after lysis of the cells $\left(=\mathrm{PHI}_{\max }\right)$ may be an additional parameter for differentiation of meningitis. In bacterial meningitis, this value was always in excess of $200 \mathrm{U} / 1$, and in half of the cases even between 1500 and $7000 \mathrm{U} / \mathrm{l}$. Viral meningitis showed results of less than $150 \mathrm{U} / \mathrm{l}$. The phosphohexose isomerase activity reached a value over $200 \mathrm{U} / 1$ in only one case (213 U/l).

For comparison, the leukocyte counts per $\mu$ are also listed in this figure. They are between 72 and 17000 per $\mu \mathrm{l}$ in bacterial meningitis and between 13 and 1440 per $\mu \mathrm{l}$ in viral meningitis. Bacterial meningitis with less than 800 leukocytes per $\mu$ loccurred six times and viral meningitis with more than 800 cells 12 times.

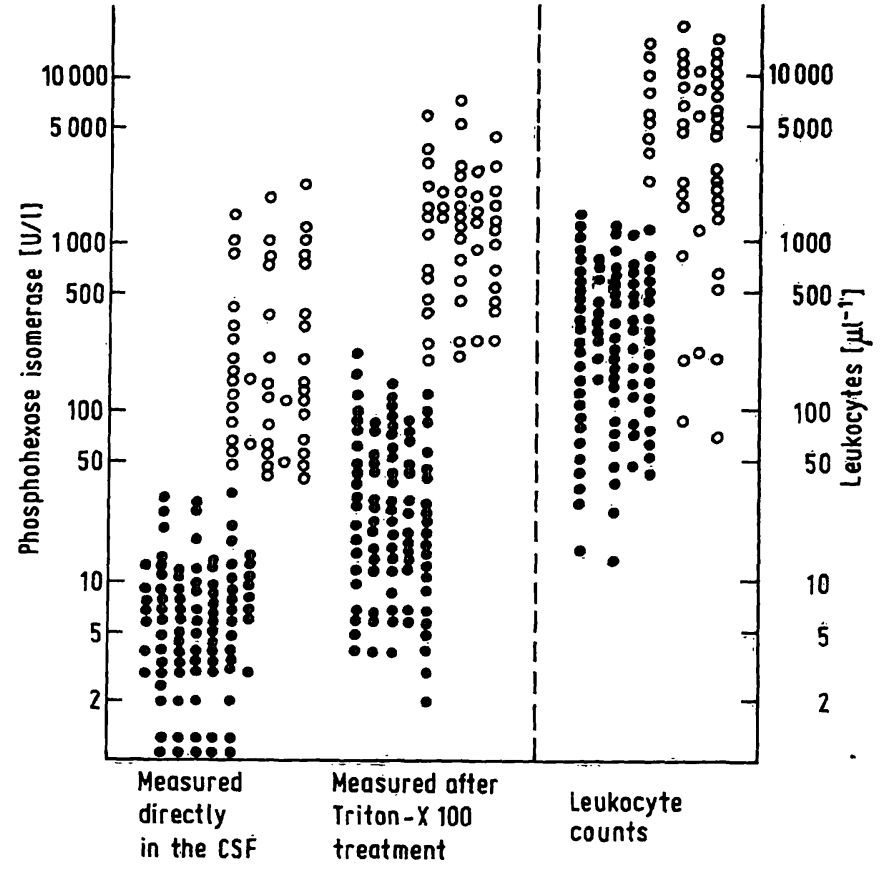

Fig. 1. Distribution of phosphohexose isomerase activities and leukocyte counts in bacterial (0) and viral (๑) meningitis.

The three viral meningitis cases with the highest cell counts and the three bacterial meningitis cases with the lowest cell counts are listed in table 1 to illustrate the good differential diagnosis between viral and bacterial meningitis. In viral meningitis, the enzyme activities were very much less than the borderline values of 40 and $200 \mathrm{U} / 1$, respectively, whereas in bacterial meningitis they were markedly higher than these limiting values.

Six patients were admitted to the hospital with bacterial meningitis after 2 to 14 days of antibiotic treatment. The laboratory findings at the time of the first lumbar puncture are shown in table 2. Out of these six patients, only two showed values for $\mathrm{PHI}_{\mathrm{dir}}$ above the limit of $40 \mathrm{U} / \mathrm{l}$ and three showed values for $\mathrm{PHI}_{\max }$ over $200 \mathrm{U} / \mathrm{1}$.

Since it is assumed that phosphohexose isomerase in meningitis originates from the leukocytes, this enzyme should also be detectable in lymphocytes and granulocytes in the absence of the disease. To confirm this hypothesis, enzyme activity was determined in lymphocytes and granulocytes isolated from donor blood (fig. 2). The phosphohexose isomerase activities for isolated lymphocytes are very low and only 22 $\mathrm{U} / 1$ were recorded, even at cell counts of 22300 per $\mu$ l. At 2100 cells per $\mu$, as is occasionally found as the upper limit in viral meningitis, this value is only $5 \mathrm{U} / \mathrm{l}$, reaching $52 \mathrm{U} / \mathrm{l}$ after lysis of the cells. On the other hand, the corresponding activities found for granulocytes are roughly eight times higher. 
Tab. 1. Phosphohexose isomerase in viral meningitis (high white blood cell counts) and in bacterial meningitis (low whitc blood cell counts).

\begin{tabular}{lllll}
\hline Patient & $\begin{array}{l}\text { Leukocytes } \\
\left(\mu \mathrm{I}^{-1}\right)\end{array}$ & $\begin{array}{l}\mathrm{PHI}_{\text {dir }} \\
(\mathrm{U} / \mathrm{l})\end{array}$ & $\begin{array}{l}\mathrm{PHI}_{\text {max }} \\
(\mathrm{U} / \mathrm{l})\end{array}$ & Pathogen \\
\hline J.C. & 1215 & 10 & 47 & Mumps \\
M.T. & 1302 & 3 & 32 & Herpes \\
S.O. & 1444 & 6 & 45 & Mumps \\
J.K. & 208 & 393 & 466 & Streptococcus group B \\
N.B. & 91 & 327 & 474 & Streptococcus pneumoniae \\
G.A. & 72 & 212 & 268 & Streptococcus pneumoniae \\
\hline
\end{tabular}

Tab. 2. Leukocyte counts and phosphohexose isomerase activities in treated bacterial meningitis.

\begin{tabular}{|c|c|c|c|c|c|c|}
\hline \multirow[t]{2}{*}{ Patient } & \multirow[t]{2}{*}{ Pathogen } & \multirow{2}{*}{$\begin{array}{l}\text { Leukocytes } \\
\left(\mu 1^{-1}\right)\end{array}$} & \multirow{2}{*}{$\begin{array}{l}\mathrm{PHI}_{\text {dir }} \\
(U / 1)\end{array}$} & \multirow{2}{*}{$\begin{array}{l}\mathrm{PHI}_{\max } \\
(\mathrm{U} / \mathrm{l})\end{array}$} & \multicolumn{2}{|c|}{ Antibiotic therapy } \\
\hline & & & & & $\begin{array}{l}\text { Treatment } \\
\text { (d) }\end{array}$ & Drug \\
\hline $\begin{array}{l}\text { H.D. } \\
\text { J.T. } \\
\text { C.S. } \\
\text { H.H. } \\
\text { M.W. } \\
\text { Y.K. }\end{array}$ & $\begin{array}{l}\text { Haemophilus influenzae } \\
\text { Unknown } \\
\text { Unknown } \\
\text { Haemophilus influenzae } \\
\text { Streptococcus pneumoniae } \\
\text { Streptococcus pneumoniae }\end{array}$ & $\begin{array}{r}3733 \\
2044 \\
1875 \\
1076 \\
366 \\
217\end{array}$ & $\begin{array}{r}37 \\
23 \\
21 \\
275 \\
8 \\
71\end{array}$ & $\begin{array}{l}328 \\
518 \\
198 \\
382 \\
120 \\
115\end{array}$ & $\begin{array}{r}2 \\
14 \\
2 \\
2 \\
2 \\
5\end{array}$ & $\begin{array}{l}\text { Erythromycin } \\
\text { Erythromycin } \\
\text { Rifampicin } \\
\text { Streptomycin + Penicillin G } \\
\text { Ampicillin } \\
\text { Amoxicillin }\end{array}$ \\
\hline
\end{tabular}

The metabolically active leukocytes that occur in meningitis can only be studied by using lymphocyte model systems. These were stimulated by three different mitogens. The increase in enzyme activity observed was on average about 10 times that of nonstimulated lymphocytes and about twice that of the lysed cells. Since the responses to each mitogen were almost identical, only the results for stimulation with phytohemagglutinin are shown in figure 2.

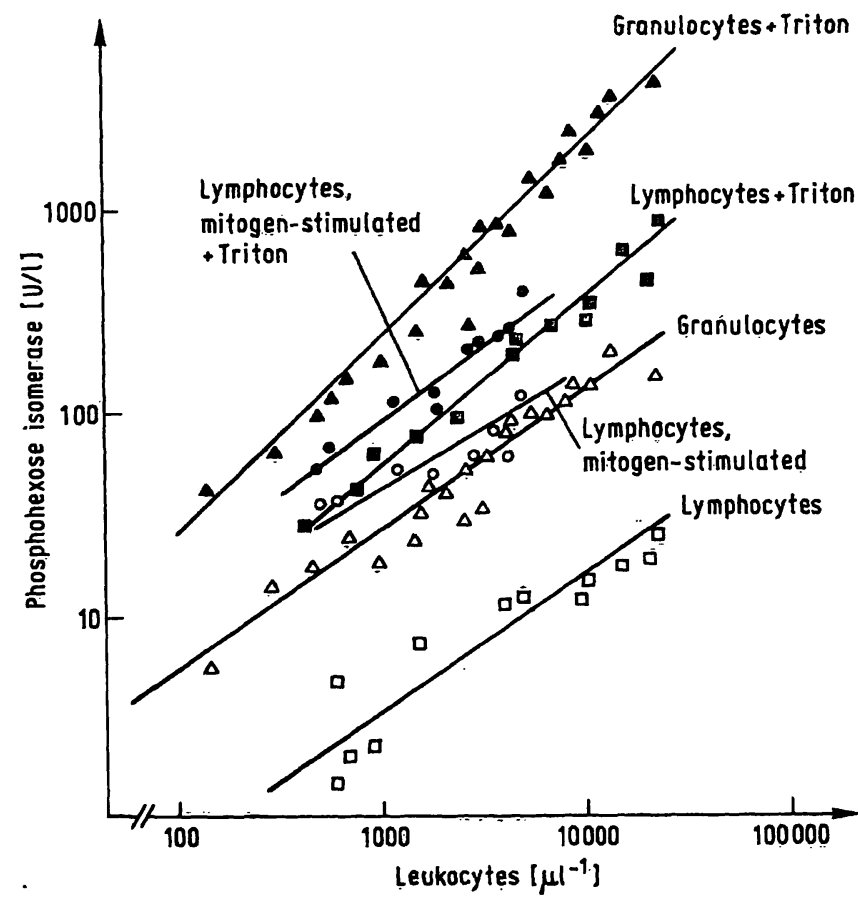

Fig. 2. Phosphohexose isomerase activities in intact and Triton $\mathrm{X}-100$ lysed lymphocytes and granulocytes as well as in mitogen-stimulated lymphocytes with and without Triton X-100.

\section{Discussion}

Together with the cases communicated in an earlier publication (2), results are now available from 77 bacterial and 153 viral meningitis cases for appraisal of the diagnostic value of phosphohexose isomerase determination in meningitis. Values of more than $40 \mathrm{U} / 1$ for $\mathrm{PHI}_{\mathrm{dir}}$ indicate the presence of bacterial meningitis. For methodological reasons, this cut-off point is $10 \mathrm{U} / 1$ lower than the value stated previously. The method differentiated correctly in 229 of the total of 230 meningitis cases. The enzyme activity was above the limit values only in one case of viral meningitis. The maximum amount of enzyme measurable after destruction of the cells is also suitable as a diagnostic measure, the limit value in this case being $200 \mathrm{U} / 1$.

The increase of phosphohexose isomerase activity in CSF after lysis of the leukocytes at temperatures over $0{ }^{\circ} \mathrm{C}$ or by treatment with Triton $\mathrm{X}-100$ indicate that these cells are the source of the enzyme. Furthermore, it can be inferred from the observations on meningitis that granulocytes release more phosphohexose isomerase than do lymphocytes.

Investigations on isolated cell suspensions do indeed reveal considerable differences in enzyme production between lymphocytes and granulocytes and in addition between stimulated and non-stimulated cells. Mitogen treatment of the lymphocytes shows that phosphohexose isomerase does not only appear passively in the CSF after cell death, but is also actively secreted by the cells. Only in this way can it be 
explained why the enzyme activities rise further to about threefold after destruction of the stimulated cells with Triton.

In the evaluation of phosphohexose isomerase activities of granulocytes, it must be taken into account that the latter cannot be stimulated like lymphocytes. However, because of the sensitivity of the granulocytes, even the individual separation steps in their isolation cause stimulation of cell metabolism, so that nonstimulated granulocytes cannot be exactly compared with nonstimulated lymphocytes.

Compared with the moderate activation in cell preparations, the acute inflammatory process in meningitis can be expected to cause a substantial increase of metabolism in the granulocytes and a corresponding increase of phosphohexose isomerase production. The granulocyte turnover and glycolytic activity should be greater the longer the meningitis has been present at the time of its diagnosis. The severity of the disease is also thought partly to determine the degree of leukocyte turnover and thus finally the degree of lysis of these cells. Thus endotoxins and other bacteriological products occasionally lead to a delayed stimulation of the granulocytes. Connected with this are prognostically unfavorable disease courses, such as are occasionally observed in pneumococcal meningitis.

The level of the phosphohexose isomerase activity evidently does not depend solely on the number and type of leukocytes but also on their glycolytic activity. Since the degree of autolysis of the leukocytes can also be expected to vary, depending on the length of time from the outbreak of the disease up to its diagnosis, a correlation between cell count and enzyme activity is not likely at the time of the first lumbar puncture, and in fact no correlation was found $(r=$ 0.24).

\section{Conclusion}

(Phosphohexose isomerase is formed in the leukocytes. Since phosphohexose isomerase production depends on the type of cell and its metabolic state, this enzyme reflects the acute process of inflammation in meningitis. The simple enzyme assay in the CSF, which can be performed rapidly and with great accuracy, thus crucially improves the reliability of the leukocyte count and the differential cell count which are still the most important clinical laboratory parameters in the diagnosis of meningitis.

\section{References}

1. Martin, W. J. (1983) Am. J. Med. (Infectious Diseases Symposium) $75,119-123$.

2. Mathias, D. (1980) Eur. J. Pediatr. 134, 75-78.

3. Koneman, E. W., Allen, S. D., Dowell, V. R. \& Sommers, H. M. (1983) Diagnostic microbiology. J. B. Lippincott Company, Philadelphia.

4. Thomas, L. (1983) Enzyme. In: Labor und Diagnose (Thomas, L., ed.) 2. Auflage, pp. 104-106. Die Medizinische Verlagsgesellschaft, Marburg/Lahn.

5. Schmolke, B. \& Vorlaender, K. O.. (1983) Standardtechniken zur Bestimmung zellulärer Immunreaktionen. In: Immunologie (Vorlaender, K. O., ed.) 2. Auflage, pp. 229241. Thieme, Stuttgart, New York.

Dr. Dr. Dietger Mathias Universitäts-Kinderklinik Im Neuenheimer Feld 150 D-6900 Heidelberg 